\title{
Individual and combined effects of heavy metals on estuarine infaunal communities
}

\author{
Atsuko Fukunaga ${ }^{1, *}$, Marti J. Anderson ${ }^{2}$, Jenny G. Webster-Brown ${ }^{3}$, \\ Richard B. Ford ${ }^{4}$ \\ ${ }^{1}$ Leigh Marine Laboratory, University of Auckland, PO Box 349, Warkworth, New Zealand \\ ${ }^{2}$ Institute of Information and Mathematical Sciences, Massey University, Albany Campus, Private Bag 102-904, \\ North Shore Mail Centre, Auckland, New Zealand \\ ${ }^{3}$ Department of Chemistry, University of Auckland, Private Bag 92019, Auckland, New Zealand \\ ${ }^{4}$ Ministry of Fisheries, ASB House, 101 The Terrace, Wellington, New Zealand
}

\begin{abstract}
Heavy metals are anthropogenically introduced into estuaries and cause lethal and sublethal effects on estuarine organisms. Copper $(\mathrm{Cu})$, lead $(\mathrm{Pb})$ and zinc $(\mathrm{Zn})$ are primary sediment contaminants of concern in Auckland, New Zealand. Their concentrations in estuarine sediments tend to correlate with one another spatially across the region, and concentrations of $\mathrm{Cu}$ and Zn are predicted to increase over time. A field experiment was done in Orewa estuary, Auckland, to assess the potential effects of $\mathrm{Cu}, \mathrm{Pb}$ and $\mathrm{Zn}$, individually and in a mixture, on estuarine communities. Surface sediments were replaced with defaunated sediment discs spiked with either $\mathrm{Cu}\left(110 \mu \mathrm{g} \mathrm{g}^{-1}\right), \mathrm{Pb}(85 \mu \mathrm{g}$ $\left.\mathrm{g}^{-1}\right)$ or $\mathrm{Zn}\left(500 \mu \mathrm{g} \mathrm{g}^{-1}\right)$, or a mixture of these 3 metals. Infaunal recolonisation was examined after 10 and $20 \mathrm{~d}$. The control, having non-spiked sediments, and the Pb treatment had significantly higher average infaunal abundances and species richness than the $\mathrm{Cu}, \mathrm{Zn}$ or mixed treatments. The structure of infaunal assemblages in the control and the $\mathrm{Pb}$ treatment differed significantly from those in the $\mathrm{Cu}$ or $\mathrm{Zn}$ treatments, which had lower abundances of polychaetes and the bivalve Macomona liliana. Differential sensitivities of different taxa to the 3 different metals resulted in greater overall impacts on community structure for the mixed treatment than for the treatments spiked with individual metals alone. This experiment clearly showed adverse effects of $\mathrm{Cu}$ and $\mathrm{Zn}$ on estuarine infauna in the field, indicating that potential increases in metal concentrations in New Zealand's estuaries through time should be treated as a serious environmental concern.
\end{abstract}

KEY WORDS: Heavy metal · Manipulative experiment · Infauna $\cdot$ Community structure $\cdot$ Estuary New Zealand

Resale or republication not permitted without written consent of the publisher

\section{INTRODUCTION}

Aquatic ecosystems are often exposed to multiple anthropogenic stressors simultaneously (Halpern et al. 2007). Heavy metals entering estuaries through urban runoff are of environmental concern (Laws et al. 1994, ARC 2004), and under estuarine conditions, suspended sediments transporting these pollutants coagulate and tend to rapidly settle, becoming incorporated into sediments (ARC 2004). Heavy metals have the potential to cause individual-level effects, such as DNA base modification (Avery et al. 1996), developmental abnormali- ties (Lavolpe et al. 2004), depression in post-exposure feeding (Moreira et al. 2006), avoidance behaviour (Roper \& Hickey 1994, Bat \& Raffaelli 1998), and mortality (Bat \& Raffaelli 1998, Gale et al. 2006). Such individual-level effects, in turn, can affect these systems as a whole at population or community levels by changing recruitment, abundances, species richness, diversity and community composition (Lande 1977, Rygg 1985, Watzin \& Roscigno 1997, Warwick 2001). Concerns regarding the cumulative or interactive effects of multiple stressors on aquatic ecosystems were raised a decade ago (Breitburg et al. 1999), and the effects of 
heavy metals have also been examined in combinations with other environmental stressors such as salinity, temperature and other toxicants (Heugens et al. 2002, Millward et al. 2004).

Estuarine infaunal organisms inhabiting soft sediments play an important role in the food chain, obtaining carbon energy from detritus or suspended organic matter in the water column and passing it to higher trophic levels (Wilson 2002). Therefore, changes in the infaunal community are likely to result in changes to the ecological functions of estuarine habitats as a whole. Hence, examining potential effects of metal contaminants on estuarine infaunal communities is vital in the assessment of anthropogenic impacts on coastal ecosystems. Field experiments have shown that increased copper concentrations in estuarine sediments negatively impact the abundances of various infaunal taxa (Morrisey et al. 1996, Lenihan et al. 2003, Trannum et al. 2004). Simultaneous effects of a mixture of multiple heavy metals have also been experimentally examined in the field or in a microcosm (Millward et al. 2004, Lu \& Wu 2007). These experiments, however, were not designed to distinguish effects of individual metals from the effects of a mixture of multiple metals (but see Lindegarth \& Underwood 2002).

The primary sediment contaminants of concern in the region of Auckland, New Zealand, include the heavy metals copper $(\mathrm{Cu})$, lead $(\mathrm{Pb})$ and zinc $(\mathrm{Zn})$ (ARC 2004). Concentrations of these metals in the sediments tend to be positively correlated with one another (Hewitt et al. 2009), and $\mathrm{Cu}$ and $\mathrm{Zn}$ concentrations in estuarine sediments are predicted to increase over time across the Auckland region (Green et al. $2004 a, b)$. In the present study we describe a manipulative field experiment done in the Orewa estuary of the Auckland region to assess the potential effects of $\mathrm{Cu}_{\text {, }}$ $\mathrm{Pb}$ and $\mathrm{Zn}$ on estuarine communities. The experiment focused on measuring the recolonisation of defaunated metal-spiked sediment by infaunal organisms over a period of $20 \mathrm{~d}$.

The main purpose of the experiment was to investigate the potential effects of the 3 primary sediment contaminants of concern $(\mathrm{Cu}, \mathrm{Pb}$ and $\mathrm{Zn})$, individually and in a mixture, on Auckland's estuarine communities in the future. Thus, target metal concentrations in the experiment were set as high as would be realistic for Auckland estuaries given predictions of potential inputs expected over the next $100 \mathrm{yr}$ (Green et al. 2004a,b). It was hypothesised that sediments spiked with heavy metals $(\mathrm{Cu}, \mathrm{Pb}$ or $\mathrm{Zn})$ would have lower abundances of colonists and, therefore, would have different faunal assemblages compared to those without additional metals. It was also hypothesised that sediments spiked simultaneously with multiple metals would result in an even greater overall reduction in the abundances of colonists and, therefore, would differ in community structure from those spiked with either a single metal or sediments with no additional metals.

\section{MATERIALS AND METHODS}

Study site and experimental design. Orewa estuary (Fig. 1) is located $\sim 30 \mathrm{~km}$ north of Auckland city and is a small to medium sized estuary with an area of $1.28 \mathrm{~km}^{2}$ below mean high water spring tide level and a catchment area of $17.5 \mathrm{~km}^{2}$. The estuary is almost completely flushed with each tide and contains extensive intertidal areas separated by channels at low tide. A square $50 \times$ $50 \mathrm{~m}$ study area $\left(36^{\circ} 35^{\prime} 45^{\prime \prime} \mathrm{S}, 174^{\circ} 40^{\prime} 51^{\prime \prime} \mathrm{E}\right)$ within an expansive mudflat at low tide was set up approximately $2 \mathrm{~km}$ upstream of the mouth of the estuary.

A colonisation experiment was done within the study area using defaunated, metal-spiked sediments. Sedi-

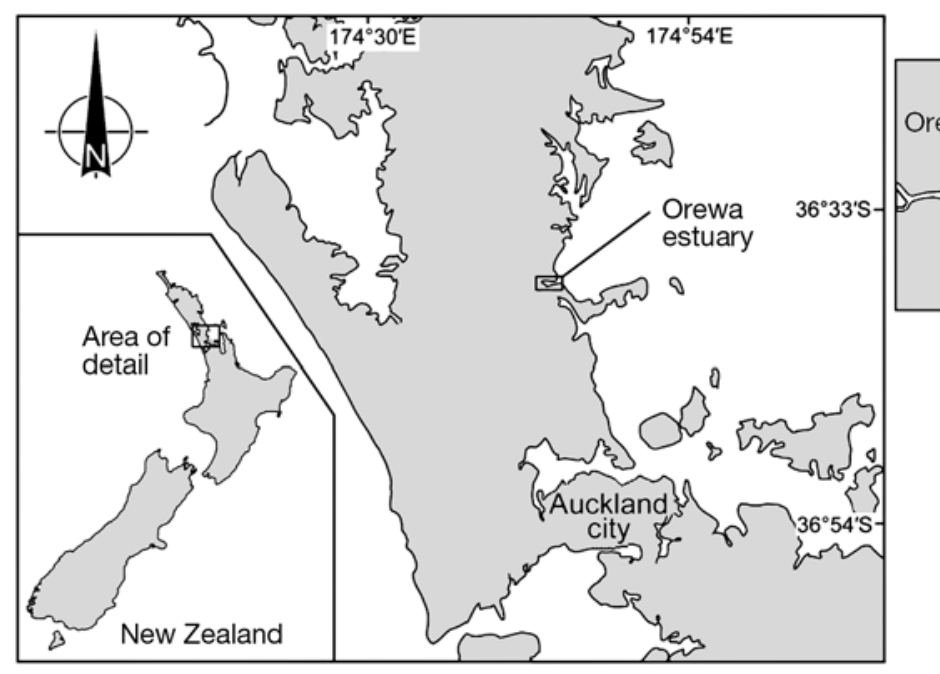

Fig. 1. New Zealand, the Auckland region, Orewa estuary and the study area $(\sim 30 \mathrm{~km}$ north of Auckland city) 
ments were collected from the surface aerobic layer (<20 $\mathrm{mm}$ in depth) at the mudflat, sieved through a $500 \mu \mathrm{m}$ mesh and spiked with metals to specific target concentrations in the laboratory, following the method of Lu et al. (2008). Briefly, sediments and seawater were poured into large barrels. The solid nitrate salts $\left(\mathrm{Cu}\left(\mathrm{NO}_{3}\right)_{2} \cdot 3 \mathrm{H}_{2} \mathrm{O}, \mathrm{Pb}\left(\mathrm{NO}_{3}\right)_{2}\right.$ and/or $\left.\mathrm{Zn}\left(\mathrm{NO}_{3}\right)_{2} \cdot 6 \mathrm{H}_{2} \mathrm{O}\right)$ were dissolved in deionised water and then added to the mixture of sediments and seawater. The barrels were placed on rotating wheels, and the contents were continously mixed for $36 \mathrm{~h}$. The initial spiking concentrations for $\mathrm{Cu}$ and $\mathrm{Zn}$ were $110 \mu \mathrm{g} \mathrm{g}^{-1}$ and $500 \mathrm{\mu g} \mathrm{g}^{-1}$, respectively. These concentrations were expected to decrease over the experimental period and to reach target concentrations of approximately $90 \mathrm{\mu g} \mathrm{g}^{-1}$ and $400 \mathrm{\mu g} \mathrm{g}^{-1}$, respectively. Although these concentrations are higher than those currently found in Auckland estuaries, they are realistic with regard to increasing levels of $\mathrm{Cu}$ and $\mathrm{Zn}$ expected with further urbanisation in the future (Green et al. 2004a,b). The target $\mathrm{Pb}$ concentrations were set at close to the highest levels that have been recorded in Auckland estuaries, with $85 \mu \mathrm{g} \mathrm{g}^{-1}$ as the initial concentration and $70 \mu \mathrm{g}$ $\mathrm{g}^{-1}$ as the ending target (Kelly 2007).

There is currently some uncertainty in predictions of $\mathrm{Pb}$ concentrations over time as the main source of $\mathrm{Pb}$ in stormwater runoff is from residues of historic paint and petrol, and these contributions are expected to diminish with time (Timperley et al. 2005). Lead is, however, still present on road surfaces, and there may be some contribution from vehicle tires (Kennedy 2003). Therefore, $\mathrm{Pb}$ concentrations may or may not increase over time.

The metal-spiked sediments were poured into polyvinylchloride (PVC) moulds (300 $\mathrm{mm}$ in diameter, $30 \mathrm{~mm}$ in depth) to create sediment discs 25 to $30 \mathrm{~mm}$ thick and were frozen at $-20^{\circ} \mathrm{C}$ for a maximum of $2 \mathrm{wk}$. On 5 August 2008 (Day 0) these discs were taken out of the models and laid out within the study area by replacing existing surface sediments with the prepared discs. A small piece of PVC $(20 \times$ $20 \mathrm{~mm}$ ) was placed underneath each sediment disc to determine relative changes in the thickness of the sediment discs in the course of the study. There were 6 different treatments in the experiment: unmanipulated (no replacement of the surface sediment), a manipulated control (surface sedi- ments that were removed, defaunated and replaced but had no additional metals), Cu treatment (sediments spiked to a target $\mathrm{Cu}$ concentration of 110 to $90 \mathrm{\mu g} \mathrm{g}^{-1}$ ), $\mathrm{Pb}$ treatment (85 to $70 \mu \mathrm{g} \mathrm{g}^{-1}$ ), Zn treatment (500 to $400 \mathrm{\mu g} \mathrm{g}^{-1}$ ) and mixed treatment (sediments spiked with all 3 metals at their respective target concentrations). The placement of the sediment discs at the site was based on a randomised block design with 16 blocks (Fig. 2). Each block contained the 6 treatments placed in a randomised array of $2 \times 3$ sampling sites, $3 \mathrm{~m}$ apart from one another. Sediment discs in different blocks were at least $6 \mathrm{~m}$ apart.

Infaunal sampling. Sediment cores $(200 \mathrm{~mm}$ in diameter, $50 \mathrm{~mm}$ in depth) from 8 of the 16 blocks ( $\mathrm{n}=$ 48) were taken inside each sediment disc on 15 August (Day 10) and from the remaining 8 blocks $(n=48)$ on 25 August (Day 20). The blocks sampled at a given point in time were chosen in a way that avoided sampling any adjacent blocks on the same day (Fig. 2). Sediment cores were extracted and sieved through $500 \mu \mathrm{m}$ mesh at the site. Material retained on sieves from each sample was brought back to the laboratory and preserved in $10 \%$ formalin for a minimum of $48 \mathrm{~h}$. Organisms

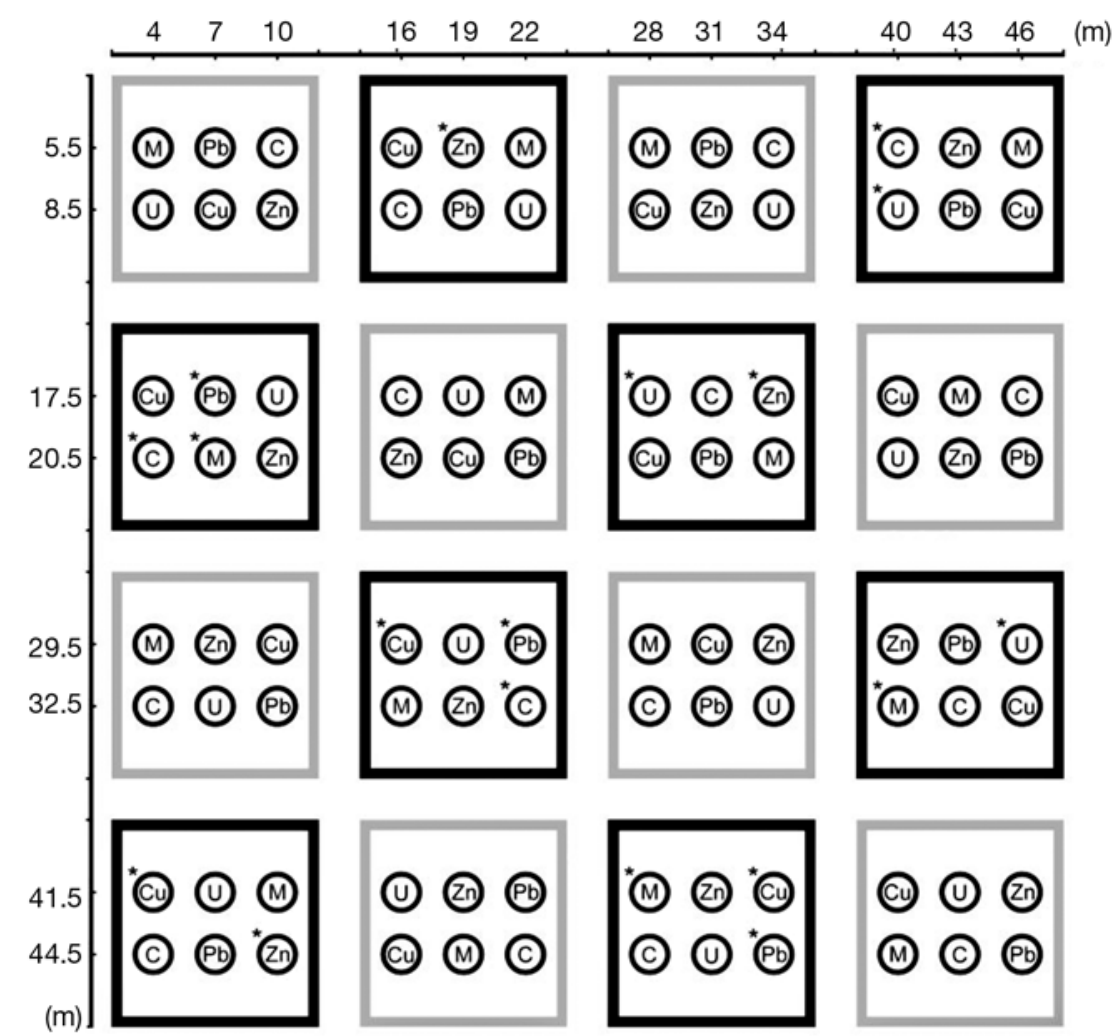

Fig. 2. Field experimental design containing 16 blocks: 8 (grey outline) were sampled on Day 10, and (black outline) on Day 20. ${ }^{*}=$ discs assigned for the monitoring of chlorophyll $a$ and porewater metal concentrations. Treatment: $U=$ unmanipulated, $\mathrm{C}=$ control, $\mathrm{Cu}=$ copper, $\mathrm{Pb}=$ lead, $\mathrm{Zn}=$ zinc, $\mathrm{M}=$ mixed metal 
were sorted from this material, preserved in $70 \%$ isopropanol, identified to the lowest practical taxonomic level and counted. All organisms identified and counted were assumed to be alive at the time of sampling. Although separating living from non-living organisms would have been desirable in order to quantify explicitly any potential post-colonisation mortality (e.g. see 'Discussion'), this was not strictly possible, as organisms were necessarily killed by fixation with formalin as part of the sampling procedure.

Environmental variables. Before the experiment began, levels of contaminants and total organic matter (TOM) in the unmanipulated and spiked sediments were assessed. For spiked sediments, 3 replicate samples of sediment were taken from each treatment prior to freezing sediment discs. For the unmanipulated treatment, 3 sediment cores $(20 \mathrm{~mm}$ in diameter, $20 \mathrm{~mm}$ in depth) were randomly taken from the study area on Day 0 prior to the introduction of the sediment discs. Sediments were dried in an oven at $60^{\circ} \mathrm{C}$ for $24 \mathrm{~h}$. Metal concentrations in the sediment samples were determined by flame atomic absorption spectroscopy (FAAS) following digestion of $0.5 \mathrm{~g}$ of the total sediment fraction in aqua regia $\left(\mathrm{HCl}: \mathrm{HNO}_{3}=3: 1\right)$ using high-purity $\mathrm{HCl}$ and $\mathrm{HNO}_{3}$ (Chen \& Ma 2001). The remaining samples were used to measure TOM by combusting the dried sediment at $500^{\circ} \mathrm{C}$ for $4 \mathrm{~h}$ (Byers et al. 1978). TOM (\%) was calculated by the weight loss after combustion. At the time of infaunal sampling on Days 10 and 20 each, sediment cores were taken adjacent to the sediment cores extracted for infaunal sampling to measure the sediment concentrations of metals and TOM associated with each disc. Metal concentrations and TOM were determined as described above.

From each treatment 3 discs were also assigned for temporal monitoring of chlorophyll a ( $\mathrm{chl}$ a) levels and concentrations of metals in the porewater. These discs were randomly chosen from the blocks scheduled for infaunal sampling on Day 20. For chl a analysis, these sediment samples (20 $\mathrm{mm}$ in diameter, $2 \mathrm{~mm}$ in depth) were taken on Day 1, 5, 12 and 20 using a syringe. The amount of chl a was determined by the spectrophotometric method according to Parsons et al. (1984) following extraction of chl $a$ in $90 \%$ acetone for $24 \mathrm{~h}$ at $4{ }^{\circ} \mathrm{C}$ in the dark. To measure metal concentrations in the porewater, peepers (uncontrolled dialyser sampler, $37 \mu \mathrm{m}$ mesh) were inserted into the selected sediment discs to collect porewater samples from the aerobic sediment layer (Adams et al. 2003). These samples were collected over 3 different periods: from Day 1 to 5, Day 5 to 12 and Day 12 to 20. Porewater samples were filtered with a $0.45 \mu \mathrm{m}$ membrane and acidified with high-purity $\mathrm{HNO}_{3}$. Porewater analysis was first attempted using graphite-furnace atomic absorption spectroscopy (GFAAS) as metal concentrations in porewater are generally relatively low. However, due to interference by components found in seawater, samples were analysed using FAAS instead. Detection limits of $\mathrm{Cu}, \mathrm{Pb}$ and $\mathrm{Zn}$ were $0.1,0.5$, and $0.1 \mathrm{mg} \mathrm{l}^{-1}$, respectively. Porewater concentrations of $\mathrm{Pb}$ were too low to be measured by FAAS, so samples of the $\mathrm{Pb}$ and mixed treatments were analysed by Hill Laboratories (Hamilton, New Zealand) using inductively coupled plasma-mass spectrometry (ICP-MS). Detection limit of $\mathrm{Pb}$ using ICP-MS was $0.001 \mathrm{mg} \mathrm{l}^{-1}$. The effects of chl $a$ and porewater sampling on infauna were considered negligible (1) because these sampling procedures avoided the centre of the sediment discs where infaunal samples were taken, and (2) because the area disturbed by the sampling was relatively small in comparison to the size of sediment discs.

Relative changes in sediment bed height (i.e. erosion or accretion) were determined by measuring sediment thickness, above the PVC pieces placed underneath sediment discs, every $5 \mathrm{~d}$. Temperature and precipitation were also monitored throughout the experiment for potential weather anomalies that could affect runoff and experimental results. A temperature recorder $\left(\mathrm{HOBO}^{\circledR}\right.$ Temperature/Light Pendant Data Logger) was attached to a plastic peg vertically inserted at the upstream, southern corner of the study area to record sediment surface temperature every 30 min during the experimental period. Rainfall data in Orewa estuary were obtained from the Auckland Regional Council's Geographic Information \& Mapping service (http:// maps.arc.govt.nz/website/maps/map_hydrotel.htm).

Statistical analyses. Analyses of infaunal assemblages were done using the software package PRIMER 6 (Clarke \& Gorley 2006) with the PERMANOVA+ add-on (Anderson et al. 2008). The experimental design consisted of 3 factors: Day (fixed with 2 levels: Day 10 and Day 20), Treatment (fixed with 6 levels: unmanipulated, control, $\mathrm{Cu}, \mathrm{Pb}, \mathrm{Zn}$ and mixed) and Block (random with 8 levels, nested in Day). Individual variables were analysed according to the full 3-factor design using permutational analysis of variance (PERMANOVA; Anderson 2001, McArdle \& Anderson 2001) based on Euclidean distances, with 4999 permutations of residuals under a reduced model. PERMANOVA pairwise comparisons followed the overall partitioning when significant differences were detected among the treatments. Although each pairwise test is exact, the PERMANOVA pairwise comparisons do not control formally for multiple tests, so they should be interpreted with some caution in this respect. The individual variables analysed in this way were: the total abundance of all taxa $(\mathrm{N})$, species richness $(S)$, Simpson's index of species evenness $(1-\lambda)$, and the abundances of several of the numerically dom- 
inant taxa. Abundance data were log transformed $\left(y^{\prime}=\right.$ $\ln (y+1))$ prior to the analyses to avoid high skewness and heterogeneity.

The structure of infaunal assemblages as a whole was examined using the modified Gower dissimilarity measure (Anderson et al. 2006) with logarithm base 5 . Thus, a 5-fold change in abundance was weighted equally with a change in species composition (from 0 to 1). (The range of maximum abundance was between 20 and 115 per sample for most of the numerically dominant taxa in this experiment). Non-metric multi-dimensional scaling (MDS) ordinations were done in order to visualise relationships among samples in terms of community structure. Differences in faunal assemblages among the 6 treatments were then examined by PERMANOVA on the basis of the full 3-way experimental design using 4999 permutations of residuals under a reduced model, followed by PERMANOVA pair-wise comparisons if significant differences were detected among the treatments.

Sediment sieving prior to spiking and freezing of sediment discs could affect the total organic content and the benthic diatom populations in the sediments, respectively. Chl a concentrations and TOM were therefore measured to test whether sediment discs had comparable environmental conditions. Chl a concentrations on Day 20 were first log transformed to $\left(y^{\prime}=\ln (y)\right)$ and then analysed using univariate oneway analysis of variance (ANOVA). Variation in TOM (\%) among treatments was tested separately at 3 timepoints of sampling: Day 0, Day 10 and Day 20. As for other univariate variables, analyses were done using PERMANOVA with 4999 permutations of raw data, based on Euclidean distances.

\section{RESULTS}

\section{Environmental variables}

Concentrations of $\mathrm{Cu}$ in sediment were elevated to target levels in the $\mathrm{Cu}$ and mixed metal treatments, but decreased from the initial target concentration of around $110 \mathrm{\mu g} \mathrm{g}^{-1}$ on Day 10 to below the ending target concentration of $90 \mu \mathrm{g} \mathrm{g}^{-1}$ on Day 20 (Fig. 3a). Concentrations of $\mathrm{Pb}$ in the $\mathrm{Pb}$ and mixed metal treatments showed similar trends, being elevated to around $85 \mathrm{\mu g} \mathrm{g}^{-1}$ on Day 10, but decreased to average concentrations of $60 \mathrm{\mu g} \mathrm{g}^{-1}$ on Day 20 (Fig. 3b). Concentrations of $\mathrm{Zn}$, however, did not reach the initial target concentration of $500 \mu \mathrm{g} \mathrm{g} \mathrm{g}^{-1}$; spiking only elevated them to around $400 \mu \mathrm{g} \mathrm{g}^{-1}$, and the concentrations decreased during the experiment to, on average, $290 \mu \mathrm{g}$ $\mathrm{g}^{-1}$ in the $\mathrm{Zn}$ treatment and $220 \mu \mathrm{g} \mathrm{g}^{-1}$ in the mixed treatment (Fig. 3c).
Concentrations of $\mathrm{Cu}$ in porewater were relatively stable during the experiment: around $0.3 \mathrm{mg} \mathrm{l}^{-1}$ in the $\mathrm{Cu}$ treatment and between $0.15 \mathrm{mg} \mathrm{l}^{-1}$ and $0.5 \mathrm{mg} \mathrm{l}^{-1}$ in the mixed metal treatment (Fig. 4a). Porewater concentrations of $\mathrm{Cu}$ in other treatments were mostly below $0.1 \mathrm{mg} \mathrm{l}^{-1}$, the detection limit of FAAS. Porewa-
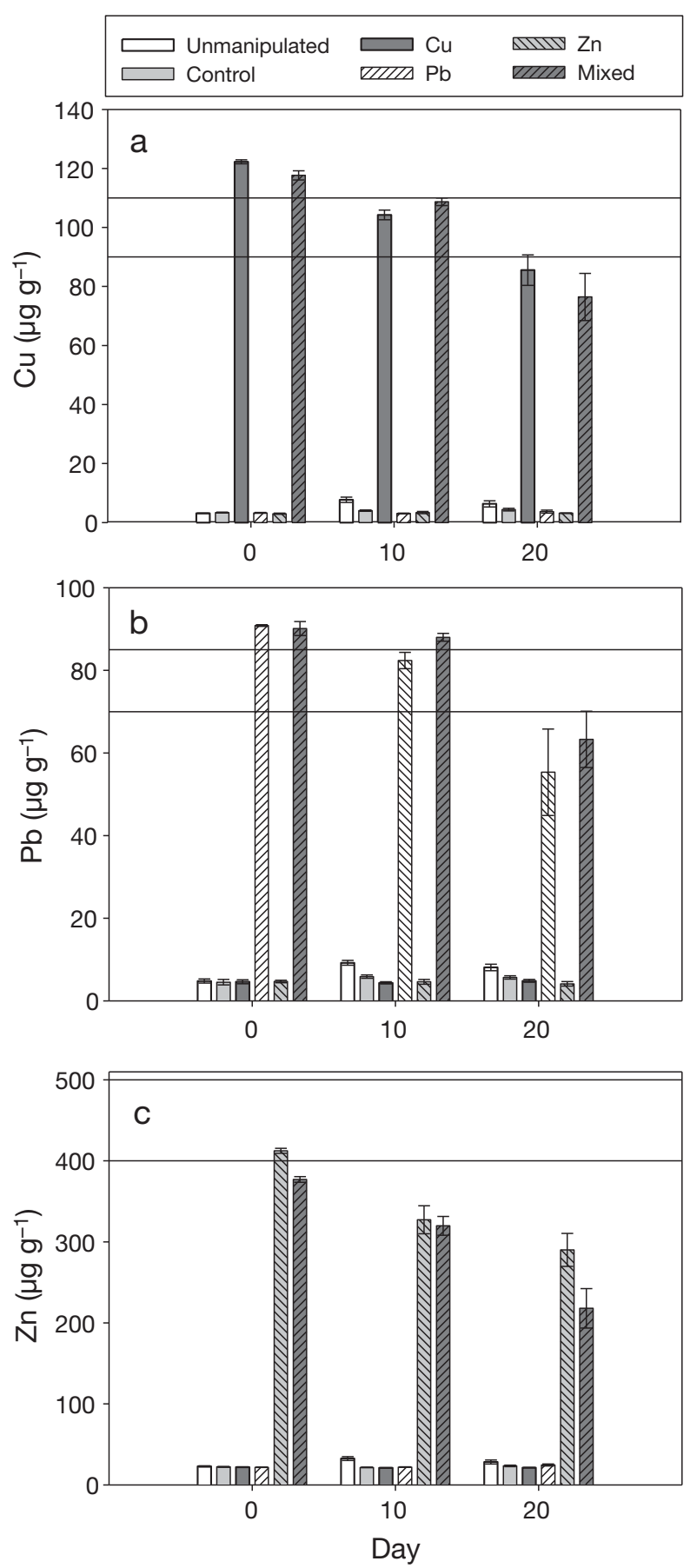

Fig. 3. Initial and final concentrations of (a) $\mathrm{Cu}$, (b) $\mathrm{Pb}$ and (c) $\mathrm{Zn}$ in sediments (mean $\pm \mathrm{SE}, \mathrm{n}=3$ ), Horizontal lines indicate the initial and ending target concentrations 

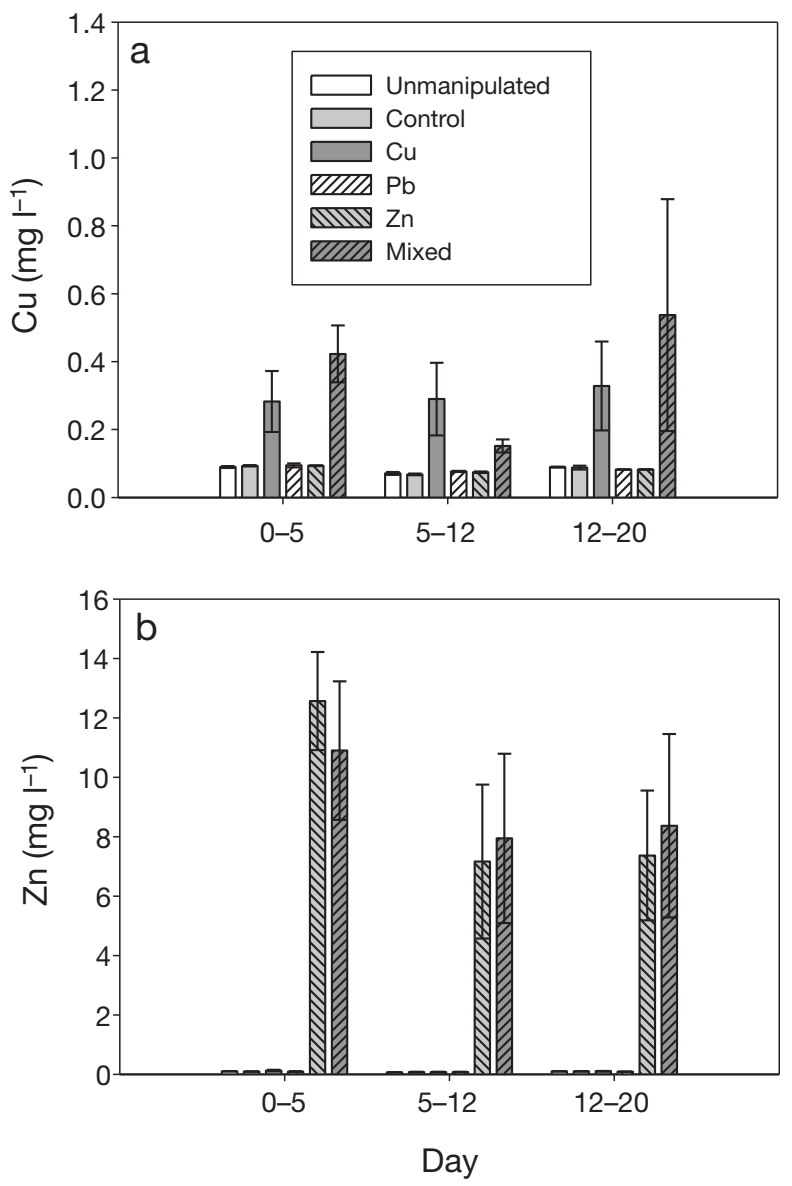

Fig 4. Concentrations of (a) $\mathrm{Cu}$ and (b) $\mathrm{Zn}$ in porewater (mean $\pm \mathrm{SE}, \mathrm{n}=3$ ) over the $20 \mathrm{~d}$ experimental period

ter concentrations of $\mathrm{Zn}$ in the treatments spiked with Zn were initially high but decreased by Day 12 to approximately $7 \mathrm{mg} \mathrm{l}^{-1}$ and stabilised (Fig. 4b). Porewater $\mathrm{Zn}$ concentrations in other treatments were mostly below the detection limit of $0.1 \mathrm{mg} \mathrm{l}^{-1}$. Porewater concentrations of $\mathrm{Pb}$ in the $\mathrm{Pb}$ and mixed metal treatments were mostly below $0.001 \mathrm{mg} \mathrm{l}^{-1}$, the detection limit of ICP-MS, except for 2 samples in the mixed treatment. These samples had $\mathrm{Pb}$ concentrations of $0.0022 \mathrm{mg} \mathrm{l}^{-1}$ (Days 5 to 12) and $0.0027 \mathrm{mg} \mathrm{l}^{-1}$ (Days 12 to 20).

Sediment chl a concentrations were mostly higher, on average, in the unmanipulated treatment compared to all the other treatments. Chl a concentrations on Day 20 were, however, not significantly $(\alpha=0.05)$ different among treatments $\left(F_{5,12}=1.36, \mathrm{p}=0.306\right)$. There was initially no significant difference in TOM levels among treatments $\left(F_{5,12}=1.02, \mathrm{p}=0.459\right)$. TOM levels were, however, significantly different among treatments on Day $10\left(F_{5,42}=15.24, \mathrm{p}=0.0002\right)$ and Day 20 $\left(F_{5,42}=5.08, \mathrm{p}=0.0022\right)$. TOM in sediments taken from
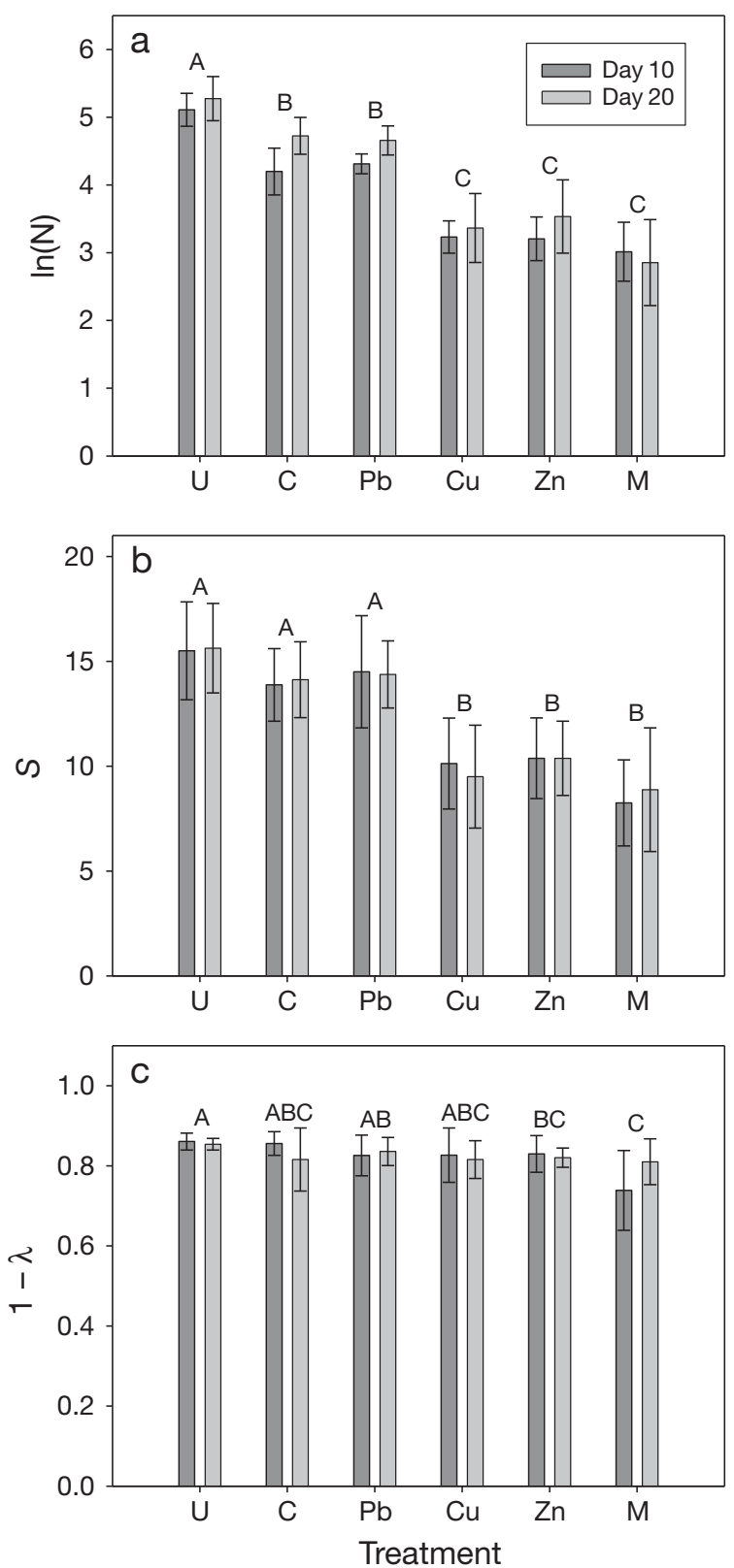

Fig. 5. Mean ( \pm SE) on Day 10 and Day 20 for (a) log-transformed total infaunal abundance $(\ln (\mathrm{N}))$, (b) species richness $(S)$ and (c) Simpson's evenness index $(1-\lambda)$ in each of the treatments: $\mathrm{U}=$ unmanipulated, $\mathrm{C}=$ control, $\mathrm{Cu}=$ copper, $\mathrm{Pb}$ $=$ lead, $\mathrm{Zn}=$ zinc, $\mathrm{M}=$ mixed metal. Means with the same letter in each graph were not significantly different (using a significance level of $\alpha=0.01$ ) based on the PERMANOVA pairwise tests

the unmanipulated treatment was significantly $(\mathrm{p}<$ 0.01) higher than those taken from all other treatments on Day 10 and from those taken from the $\mathrm{Cu}, \mathrm{Zn}$ or mixed metal treatments on Day 20. There were no significant differences in TOM levels among the control, $\mathrm{Cu}, \mathrm{Pb}, \mathrm{Zn}$ and mixed metal treatments. Monitoring of sediment disc thickness showed that the site experi- 
enced some overall erosion; the average change in bed height ranged from 0 to $-5 \mathrm{~mm}$ (erosion) during the experiment. Changes in the thickness of the sediment discs were, on average, $-3.5 \mathrm{~mm}(\mathrm{SD}=2.2)$ for those sampled on Day 10 and $-0.65 \mathrm{~mm}(\mathrm{SD}=4.2$ ) for those sampled on Day 20.

Sediment surface temperature at the study area mostly fluctuated daily between $5^{\circ} \mathrm{C}$ and $25^{\circ} \mathrm{C}$. The maximum and minimum temperatures were $25.7^{\circ} \mathrm{C}$ and $2.3^{\circ} \mathrm{C}$, respectively, and these values were both recorded on Day 5. The greatest amount of rainfall recorded with a $24 \mathrm{~h}$ period was $33.8 \mathrm{~mm}$ on Day 19.

\section{Infauna}

In total, 31 taxa were identified from the 48 sediment cores collected on Day 10 and 27 taxa from the 48 cores collected on Day 20. The numerically dominant taxa in this study were, in order of decreasing abundance, Scoloplos cylindrifer, oligochaetes, Prionospio sp., Capitella spp., Ceratonereis sp., polydorids, Paracalliope sp., Austrovenus stutchburyi, Macomona liliana, and Pectinaria australis. These 10 taxa accounted for $\sim 90 \%$ of the total abundance of all infaunal organisms. The mean log-transformed total abundance of infauna differed significantly among treatments (Table 1). The control and $\mathrm{Pb}$ treatments had significantly greater abundances of organisms than the $\mathrm{Cu}, \mathrm{Zn}$ or mixed metal treatments, on average, but significantly fewer than the unmanipulated treatment (Fig. 5a). There was also an overall increase in the total abundance of infauna from Day 10 to Day 20 (Table 1). Similarly, there were statistically significant effects of treatments on species richness (Table 1). The unmanipulated, control and $\mathrm{Pb}$ treatments had a significantly greater average number of taxa than the $\mathrm{Cu}, \mathrm{Zn}$ or mixed metal treatments (Fig. 5b). Simpson's index of species evenness also differed significantly among treatments (Table 1). Evenness was, on average, greater in the unmanipulated treatment than in the $\mathrm{Zn}$ or mixed treatments, and was also greater in the $\mathrm{Pb}$ treatment than in the mixed treatment (Fig. 5c).

Significant treatment effects were also detected for individual taxa, with the exception of the amphipod Paracalliope sp. (Table 1). Average log abundances of oligochaetes and Austrovenus stutchburyi were both significantly higher in the unmanipulated treatment than in all other treatments, suggesting an effect of the surface sediment manipulation; however, no significant differences were found among the control, $\mathrm{Cu}$, $\mathrm{Pb}, \mathrm{Zn}$ and mixed metal treatments (Fig. 6b,h). The mean log abundances of Scoloplos cylindrifer, Prionospio sp., Capitella sp., Macomona liliana and Pectinaria australis were significantly higher in the control treatment than in the $\mathrm{Cu}, \mathrm{Zn}$ or mixed metal treatments (Fig. 6). Ceratonereis sp. had significantly lower average abundances in the $\mathrm{Cu}$ and mixed metal treat-

Table 1. PERMANOVA for univariate and multivariate analyses and results of pairwise tests. Univariate analyses were for the total $\log$ abundance, species richness, Simpson's index and numerically dominant taxa, and multivariate analysis was done based on the modified Gower dissimilarity measure (log base 5) calculated on infaunal abundances on Day 10 and Day 20. Significant $\mathrm{p}$-values are printed in bold $(\mathrm{p}<0.05)$. Treatments underlined together did not show significant $(\alpha=0.01)$ difference in pairwise tests (Treatment: $\mathrm{U}=$ unmanipulated, $\mathrm{C}=$ control, $\mathrm{Cu}=$ copper, $\mathrm{Pb}=$ lead, $\mathrm{Zn}=$ zinc, $\mathrm{M}=$ mixed metal). Results of pairwise tests for the multivariate analysis are shown in Table 2

\begin{tabular}{|c|c|c|c|c|c|c|c|c|c|}
\hline & \multicolumn{2}{|c|}{ Day } & \multicolumn{2}{|c|}{ Treatment } & \multicolumn{2}{|c|}{ Block (Day) } & \multicolumn{2}{|c|}{ Day $\times$ Treatment } & \multirow{2}{*}{$\begin{array}{c}\text { Treatment } \\
\text { Pairwise test }\end{array}$} \\
\hline & $F_{1,14}$ & $\mathrm{p}$ & $F_{5,70}$ & $\mathrm{p}$ & $F_{14,70}$ & $\mathrm{p}$ & $F_{5,70}$ & $\mathrm{p}$ & \\
\hline \multicolumn{10}{|l|}{ Univariate } \\
\hline Total log abundance & 6.31 & 0.027 & 96.54 & 0.0002 & 1.52 & 0.133 & 1.70 & 0.154 & $\underline{\mathrm{U}} \underline{\mathrm{Pb} \mathrm{C}} \underline{\mathrm{Zn} \mathrm{Cu} \mathrm{M}}$ \\
\hline Species richness & 0.01 & 0.967 & 29.15 & 0.0002 & 1.14 & 0.330 & 0.15 & 0.983 & $\underline{\mathrm{U} \mathrm{Pb} \mathrm{C}} \underline{\mathrm{Zn} \mathrm{Cu} \mathrm{M}}$ \\
\hline Simpson's index & 0.03 & 0.865 & 3.08 & 0.011 & 1.24 & 0.250 & 1.43 & 0.225 & $\overline{\mathrm{UPb} \mathrm{C}} \overline{\mathrm{Cu} \mathrm{Zn} \mathrm{M}}$ \\
\hline S. cylindrifer & 3.40 & 0.082 & 94.29 & 0.0002 & 2.40 & 0.007 & 1.67 & 0.156 & $\underline{\mathrm{U}} \overline{\mathrm{C} \mathrm{Pb} \mathrm{Cu} \mathrm{Zn} \mathrm{M}}$ \\
\hline Oligochaetes & 1.50 & 0.247 & 13.20 & 0.0002 & 0.13 & 0.125 & 1.52 & 0.194 & $\underline{\mathrm{U}} \overline{\mathrm{C} \mathrm{Pb}} \overline{\mathrm{Zn} \overline{\mathrm{Cu} \mathrm{M}}}$ \\
\hline Prionospio sp. & 2.54 & 0.130 & 42.72 & 0.0002 & 1.76 & 0.062 & 1.18 & 0.328 & $\mathrm{U} \mathrm{Pb} \mathrm{C} \mathrm{M} \mathrm{Cu} \mathrm{Zn}$ \\
\hline Capitella spp. & 8.39 & 0.010 & 36.29 & 0.0002 & 1.22 & 0.279 & 1.52 & 0.188 & $\overline{\mathrm{C} \overline{\mathrm{UPb}}} \overline{\mathrm{Cu} \mathrm{Zn} \mathrm{M}}$ \\
\hline Ceratonereis sp. & 0.76 & 0.394 & 30.04 & 0.0002 & 1.44 & 0.159 & 0.20 & 0.960 & $\underline{\mathrm{U}} \underline{\mathrm{Pb} \mathrm{C} \mathrm{Zn}} \overline{\mathrm{Cu} \mathrm{M}}$ \\
\hline Polydorids & 9.43 & 0.010 & 28.40 & 0.0002 & 1.19 & 0.299 & 1.27 & 0.289 & $\underline{\mathrm{U}} \overline{\mathrm{C} \mathrm{Pb} \mathrm{Cu}} \overline{\mathrm{M} \mathrm{Zn}}$ \\
\hline Paracalliope sp. & 0.33 & 0.578 & 0.96 & 0.451 & 3.91 & 0.0004 & 0.91 & 0.485 & \\
\hline A. stutchburyi & 16.92 & 0.002 & 32.55 & 0.0002 & 2.10 & 0.024 & 0.35 & 0.888 & $\underline{\mathrm{U}} \underline{\mathrm{Zn} \mathrm{Pb} \mathrm{C} \mathrm{Cu} \mathrm{M}}$ \\
\hline M. liliana & 0.87 & 0.378 & 47.37 & 0.0002 & 1.53 & 0.130 & 0.43 & 0.824 & $\underline{\mathrm{U}} \underline{\mathrm{Cb}} \underline{\mathrm{Zn} \mathrm{Cu} \mathrm{M}}$ \\
\hline P. australis & 0.05 & 0.819 & 14.13 & 0.0002 & 1.07 & 0.395 & 2.02 & 0.084 & $\underline{\mathrm{U} \overline{\mathrm{C} \mathrm{Pb}}} \underline{\mathrm{M} \mathrm{Zn} \mathrm{Cu}}$ \\
\hline \multicolumn{10}{|l|}{ Multivariate } \\
\hline Modified Gower & 2.22 & 0.007 & 13.00 & 0.0002 & 1.64 & 0.0002 & 1.20 & 0.098 & \\
\hline
\end{tabular}



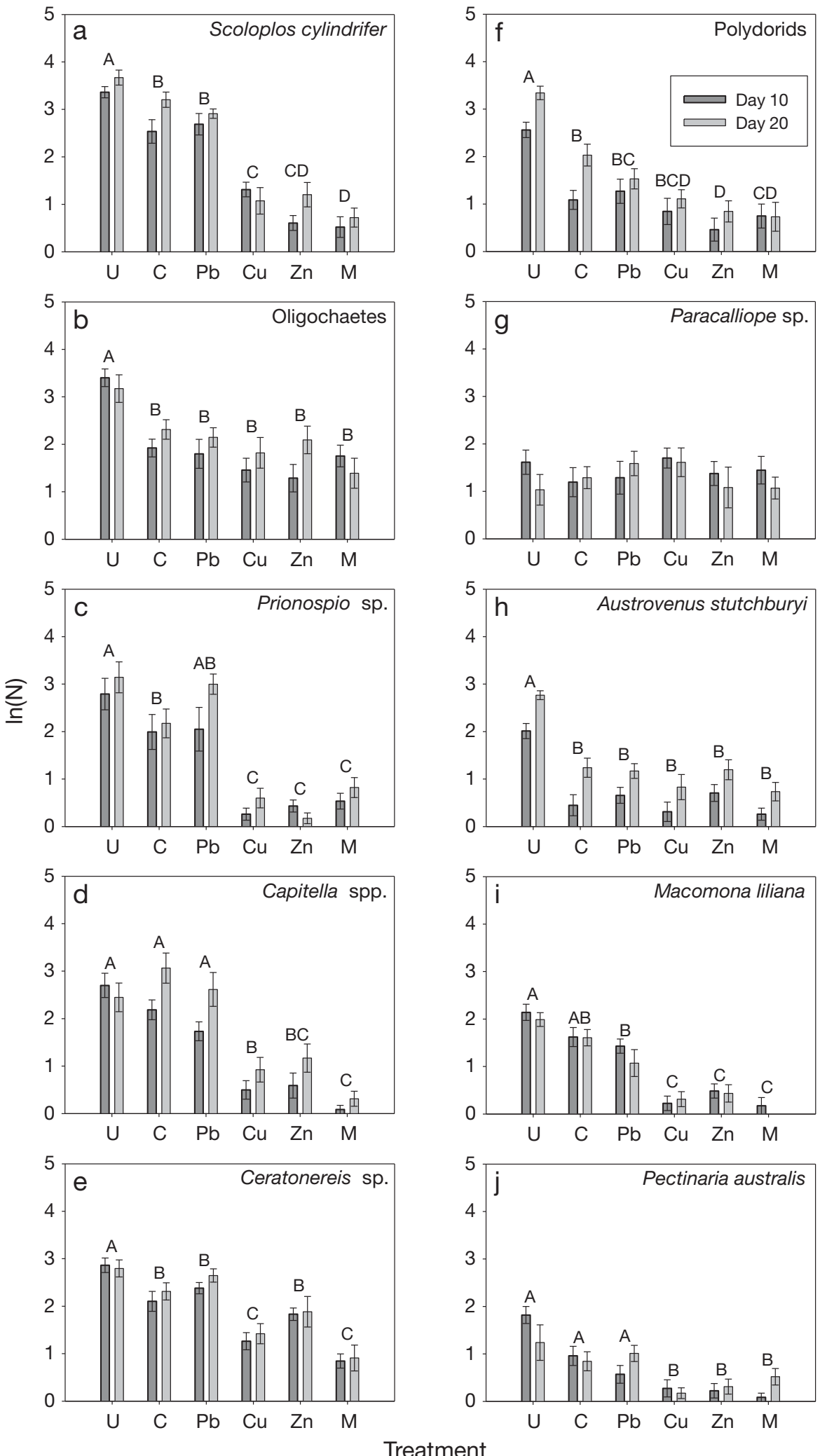

Fig. 6. Mean $( \pm \mathrm{SE}) \log$-transformed abundances $(\ln (\mathrm{N}))$ of numerically dominant taxa. Treatment: $\mathrm{U}=$ unmanipulated, $\mathrm{C}=\mathrm{con}-$ trol, $\mathrm{Cu}=$ copper, $\mathrm{Pb}=$ lead, $\mathrm{Zn}=$ zinc, $\mathrm{M}=$ mixed metal. Means with the same letter were not significantly different (using a significance level of $\alpha=0.01$ ) based on the PERMANOVA pairwise tests 
ments compared to the control (Fig. 6e), and polydorids had significantly lower average abundances in the $\mathrm{Zn}$ and mixed treatment compared to the control (Fig. 6f). None of the dominant taxa showed significant differences in their average abundances between the control and $\mathrm{Pb}$ treatments. S. cylindrifer, Capitella spp. and Ceratonereis sp. also showed significant differences in their average abundances in the mixed metal treatment versus the $\mathrm{Cu}$ or $\mathrm{Zn}$ treatments: mean log abundances of $S$. cylindrifer and Capitella spp. were significantly lower in the mixed treatment compared to the $\mathrm{Cu}$ treatment, and mean log abundance of Ceratonereis sp. was significantly lower in the mixed treatment compared to the $\mathrm{Zn}$ treatment.

Overall increases in abundance from Day 10 to Day 20 were found in Capitella spp., polydorids and Austrovenus stutchburyi (Table 1). Significant variation among blocks was also detected for Scoloplos cylindrifer, Paracalliope sp. and A. stutchburyi (Table 1), indicating high spatial variability in their distributions at scales of tens of meters.

There were significant $(\alpha=0.05)$ differences in the structure of infaunal assemblages between Day 10 and Day 20, among blocks and among treatments (Table 1). Assemblages in the unmanipulated treatment differed from all other treatments (Table 2). Assemblages in the control and $\mathrm{Pb}$ treatments did not differ significantly from one another, but were significantly different from those in the $\mathrm{Cu}, \mathrm{Zn}$ or mixed metal treatments (Table 2). Importantly, there was also a significant difference between assemblages in the mixed metal treatments and assemblages from any of the treatments spiked with only a single metal alone, whether it was $\mathrm{Cu}, \mathrm{Zn}$ or $\mathrm{Pb}$. These results were supported by patterns seen in the MDS plots (Fig. 7): assemblages from the mixed metal treatment (with all 3 metals, on the left of the diagram) were most dissimilar from those in the unmanipulated

Table 2. PERMANOVA pairwise tests $(\alpha=0.01)$ based on the modified Gower dissimilarity measure (log base 5), calculated on infaunal abundances on Day 10 and Day 20. Treatment: $\mathrm{Cu}=$ copper, $\mathrm{Pb}=$ lead, $\mathrm{Zn}=$ zinc

\begin{tabular}{|c|c|c|c|c|c|}
\hline & Unmanipulated & Control & $\mathrm{Cu}$ & $\mathrm{Pb}$ & $\mathrm{Zn}$ \\
\hline Control & $\begin{array}{l}t_{14}=2.74 \\
\mathrm{p}=0.0002\end{array}$ & & & & \\
\hline $\mathrm{Cu}$ & $\begin{array}{l}t_{14}=5.37 \\
\mathrm{p}=0.0002\end{array}$ & $\begin{array}{l}t_{14}=3.62 \\
\mathrm{p}=0.0002\end{array}$ & & & \\
\hline $\mathrm{Pb}$ & $\begin{array}{l}t_{14}=2.92 \\
\mathrm{p}=0.0002\end{array}$ & $\begin{array}{l}t_{14}=0.98 \\
\mathrm{p}=0.473\end{array}$ & $\begin{array}{l}t_{14}=3.20 \\
\mathrm{p}=0.0002\end{array}$ & & \\
\hline $\mathrm{Zn}$ & $\begin{array}{l}t_{14}=5.06 \\
p=0.0002\end{array}$ & $\begin{array}{l}t_{14}=3.37 \\
\mathrm{p}=0.0002\end{array}$ & $\begin{array}{l}t_{14}=1.32 \\
\mathrm{p}=0.061\end{array}$ & $\begin{array}{l}t_{14}=3.32 \\
\mathrm{p}=0.0002\end{array}$ & \\
\hline $\begin{array}{l}\text { Mixed } \\
\text { metal }\end{array}$ & $\begin{array}{l}t_{14}=6.04 \\
p=0.0002\end{array}$ & $\begin{array}{l}t_{14}=4.23 \\
\mathrm{p}=0.0002\end{array}$ & $\begin{array}{l}t_{14}=1.51 \\
\mathrm{p}=0.014\end{array}$ & $\begin{array}{l}t_{14}=4.24 \\
\mathrm{p}=0.0002\end{array}$ & $\begin{array}{l}t_{14}=1.89 \\
\mathrm{p}=0.0012\end{array}$ \\
\hline
\end{tabular}
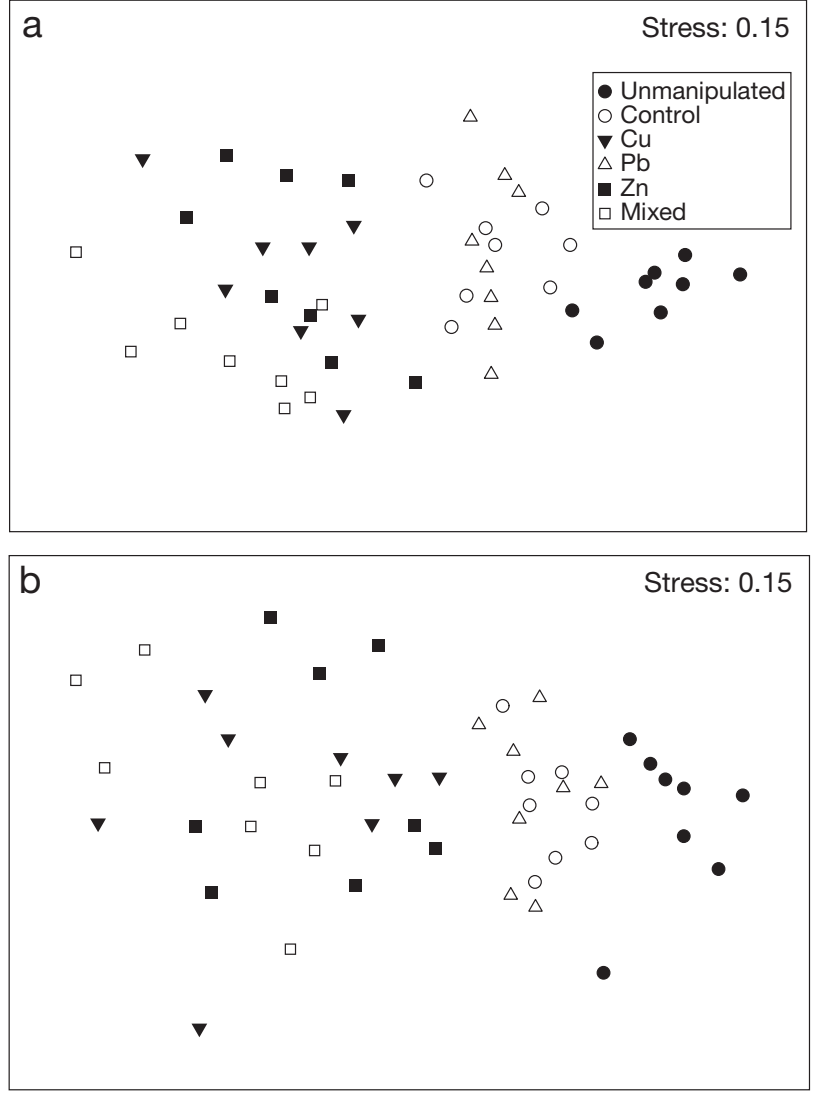

Fig. 7. MDS plots based on the modified Gower dissimilarity measure (log base 5) calculated from infaunal abundances for 31 taxa (a) on Day 10 and (b) on Day 20

treatment (on the right). In between these, assemblages from the $\mathrm{Cu}$ and $\mathrm{Zn}$ treatments were interspersed with one another, placed close to the mixed treatment. Assemblages from the control and $\mathrm{Pb}$ treatments were also well interspersed with one another, placed in-between the unmanipulated treatment and the $\mathrm{Cu}$ and $\mathrm{Zn}$ treatments. The overall pattern in the MDS was a clear gradient in effect from unmanipulated treatments on the right, to assemblages experiencing sediment manipulation or those spiked with $\mathrm{Pb}$, followed by assemblages in sediments spiked by either $\mathrm{Cu}$ or $\mathrm{Zn}$ alone, and finally assemblages which experienced elevated levels of all 3 heavy metals (the mixed metal treatment) on the far left. Although the pattern of difference between the mixed treatment and either the $\mathrm{Cu}$ or $\mathrm{Zn}$ treatments is somewhat less clear for Day 20 than 
for Day 10 in the reduced-space (2-dimensional) MDS ordination (Fig. 7), the PERMANOVA test results, which used the full resemblance matrix of information, demonstrated clear and consistent differences between the mixed treatment and either the $\mathrm{Cu}$ or $\mathrm{Zn}$ treatments (Tables $1 \& 2$ ).

\section{DISCUSSION}

Total infaunal abundance and species richness were significantly reduced by the $\mathrm{Cu}, \mathrm{Zn}$ and mixed metal treatments. Several of the numerically dominant organisms reflected this pattern. Direct negative effects of $\mathrm{Cu}$ and $\mathrm{Zn}$ on polychaetes, crustaceans and bivalves have also been found in laboratory bioassays (Bat \& Raffaelli 1998, King et al. 2004). For example, Bat \& Raffaelli (1998) showed that sediment $\mathrm{Cu}$ and $\mathrm{Zn}$ concentrations of $100 \mathrm{\mu g} \mathrm{g}^{-1}$ each caused $100 \%$ mortality of the amphipod Corophium volutator, and $90 \mu \mathrm{g}$ $\mathrm{g}^{-1}$ of $\mathrm{Cu}$ and $100 \mathrm{\mu g} \mathrm{g}^{-1}$ of Zn caused $100 \%$ mortality of the polychaete Arenicola marina. Some previous manipulative field experiments have also shown that $\mathrm{Cu}$ in sediments can significantly reduce abundances of various taxa (Morrisey et al. 1996, Lenihan et al. 2003, Trannum et al. 2004).

The bioavailability of sediment-associated metals is controlled by the metal binding strength to the sediment, and metals bound to sediments may not be toxic to organisms (Chapman \& Long 1983). Lead generally has high affinity for suspended particulate matter (Webster-Brown 2005), and binds strongly to iron and manganese oxyhydroxides, which are the dominant metal-binding phases in aerobic sediments (Gadde \& Laitinen 1974, Benjamin \& Leckie 1981b). The strong binding of $\mathrm{Pb}$ to the sediments was also evident from the extremely low $\mathrm{Pb}$ concentrations in porewater (mostly $<0.001 \mathrm{mg} \mathrm{l}^{-1}$ ) measured in this experiment. Concentrations of $\mathrm{Cu}$ and $\mathrm{Zn}$ in porewater in spiked sediments were, on the contrary, elevated to levels comparable to those reported from estuaries in the UK that had been affected by mining activities (Bryan et al. 1987, Bryan \& Langston 1992). Borgmann and Norwood (1999) examined bioavailability of $\mathrm{Pb}$ to the amphipod Hyalella azteca and showed that dissolved $\mathrm{Pb}$, rather than $\mathrm{Pb}$ associated with sediments, almost entirely explained the bioavailability and toxicity of $\mathrm{Pb}$. The lack of any apparent effects of $\mathrm{Pb}$ on recolonisation of estuarine infauna, therefore, may be explained by low bioavailability of this metal to organisms.

The experimental target concentration of $\mathrm{Pb}(85 \mu \mathrm{g}$ $\mathrm{g}^{-1}$ ) might be considered as relatively low by international standards (Long et al. 1995, ANZECC 2000). However, this concentration falls within the range of the sediment quality guidelines of Long et al. (1995), which list sediment $\mathrm{Pb}$ concentrations of $46.7 \mathrm{\mu g} \mathrm{g}^{-1}$ and $218 \mu \mathrm{g} \mathrm{g}^{-1}$ as the effects range-low (ERL) and the effects range-median (ERM), respectively. Similarly, the target $\mathrm{Cu}$ concentration of $110 \mathrm{\mu g} \mathrm{g}^{-1}$ in the present experiment was also higher than the ERL $\left(34 \mu \mathrm{g} \mathrm{g}^{-1}\right)$ but lower than the ERM (270 $\mathrm{g} \mathrm{g} \mathrm{g}^{-1}$ ) for $\mathrm{Cu}$ (Long et al. 1995). Josefson et al. (2008) suggested a threshold Pb concentration of $\sim 200 \mu \mathrm{g} \mathrm{g}^{-1}$ for deterioration of faunal communities to occur in the field. However, the sediments in that study were also contaminated with $\mathrm{Zn}$, so the contribution of $\mathrm{Pb}$ to the observed effects could not be separated and identified unambiguously. The target and ending concentrations of $\mathrm{Pb}$ in the present experiment were comparable to $\mathrm{Pb}$ concentrations in some of the most highly contaminated estuaries of the Auckland region (Kelly 2007). Our results suggest that $\mathrm{Pb}$ alone will be unlikely to cause important changes in estuarine faunal communities in this region if current $\mathrm{Pb}$ levels are maintained. Increases in concentrations of $\mathrm{Pb}$, however, may cause acute adverse effects on estuarine fauna as indicated by other studies. Potential long-term or sublethal effects of $\mathrm{Pb}$ and other metals also remain to be examined.

Different organisms had different sensitivities to heavy metals. Three taxa that apparently were not affected by $\mathrm{Cu}, \mathrm{Pb}$ or $\mathrm{Zn}$ in this experiment were the amphipod Paracalliope sp., the bivalve Austrovenus stutchburyi and oligochaetes. The insensitivity of Paracalliope sp. to heavy metals contradicts findings from other studies reporting reduced abundances of amphipods in sediments contaminated with heavy metals in the field (Morrisey et al. 1996, Warwick 2001, Lenihan et al. 2003). Laboratory bioassays have also shown sensitivity of amphipods to $\mathrm{Cu}$ and $\mathrm{Zn}$ (Bat \& Raffaelli 1998, Marsden \& Wong 2001). These laboratory bioassays, however, suggested that the $\mathrm{LC}_{50}$ values (concentration responsible for $50 \%$ mortality) could vary greatly between species and for different metals. It is therefore possible that Paracalliope sp. simply has a higher tolerance to heavy metals. Another possible explanation is that this amphipod does not experience full metal toxicity as the species is patchily distributed in the field and highly mobile.

Austrovenus stutchburyi are filter-feeding, venerid bivalves commonly found in estuaries in New Zealand, and it is perhaps surprising that no deleterious effects of metals on their colonisation were detected in this experiment. Potential effects of certain environmental stressors on this species (such as organic chemicals and sedimentation) have been examined (Hickey et al. 1995, Norkko et al. 2006), but the potential direct effects of heavy metals have not been previously tested in field-based manipulative studies. Thrush et al. (2008) demonstrated a negative correlation between 
abundances of $A$. stutchburyi and $\mathrm{Cu}$ concentrations in Auckland estuaries and harbours. De Luca-Abbott (2001) showed that sediments contaminated with $\mathrm{Cu}_{\text {, }}$ $\mathrm{Pb}, \mathrm{Zn}$ and polycyclic aromatic hydrocarbons had sublethal effects on A. stutchburyi in the field. These studies, however, did not manipulate concentrations of heavy metals directly, so direct causality cannot be inferred. Nevertheless, potential sublethal or longterm effects should be considered and investigated for this species, based on this prior work.

In contrast, the deposit-feeding tellinid bivalve Macomona liliana did show sensitivity to $\mathrm{Cu}$ and $\mathrm{Zn}$ in this experiment. The different responses to the $\mathrm{Cu}, \mathrm{Zn}$ and mixed metal treatments for M. liliana versus Austrovenus stutchburyi may have been due to differences in their feeding behaviour. Bioaccumulation of sediment-associated organic contaminants has been found to be higher in $M$. liliana than in A. stutchburyi, probably because the filter-feeding $A$. stutchburyi is unlikely to directly ingest highly contaminated surface sediments, unlike the deposit-feeding $M$. liliana (Wilcock et al. 1993, Hickey et al. 1995). Juvenile $M$. liliana can also actively disperse using bedload and water column transport (Lundquist et al. 2004), and will crawl away from sediments with $\mathrm{Cu}$ concentrations of $10 \mu \mathrm{g} \mathrm{g}^{-1}$ or Zn concentrations of $40 \mu \mathrm{g} \mathrm{g}^{-1}$ (Roper et al. 1995). Such behaviour indicates the potential ability of this species to actively avoid metal contaminants.

Annelid worms have been shown to be relatively tolerant to heavy metals in the laboratory and in the field. The polychaetes Australonereis ehlersi and Nephtys australiensis did not show lethal effects with sedimentbound $\mathrm{Cu}$ at $1300 \mu \mathrm{g} \mathrm{g}^{-1}$ or $\mathrm{Zn}$ over $3000 \mu \mathrm{g} \mathrm{g}^{-1}$ in laboratory bioassays (King et al. 2004). Polychaetes have been found in high abundances in sediments contaminated with heavy metals in the field (Lande 1977, Rygg 1985). The relative tolerance of annelids to heavy metals described in other studies is only supported by the insensitivity of oligochaetes to $\mathrm{Cu}, \mathrm{Pb}$ and $\mathrm{Zn}$ observed in the present experiment; the numerically dominant polychaetes studied here were, in contrast, all sensitive to the $\mathrm{Cu}$ and $\mathrm{Zn}$ treatments. Rygg (1985) found that the metal-tolerant species in Norwegian fjords were mostly carnivorous polychaetes, suggesting that feeding behaviour might play a role in determining the sensitivity of organisms to metals. Carnivorous polychaetes might be less affected by sediment metals than deposit-feeders because they would not ingest sediment-associated metals directly.

Capitellids have been found in high abundances in areas contaminated with heavy metals (Lande 1977) and identified as highly tolerant to $\mathrm{Cu}$ (Rygg 1985). Such findings from previous studies contradict the apparent sensitivity of Capitella spp. found in the pre- sent experiment. Capitellids (especially Capitella species) are known as $r$-selected, highly opportunistic polychaetes that quickly colonise polluted habitats (Borja et al. 2000), but their increased abundances have been found mostly in association with organic enrichment (Tsutsumi 1987, Blanchard \& Feder 2003, Lee et al. 2006), even with elevated sediment $\mathrm{Cu}$ concentrations of $500 \mathrm{\mu g} \mathrm{g}^{-1}$ (Lenihan et al. 2003). Thus, the sensitivity of capitellids to heavy metals may be affected by the amount of organics in sediments, and potential interactions between heavy metal contaminants and organics in their effects on these organisms need to be examined.

Multivariate analyses revealed that faunal assemblages in the mixed metal treatment were different from those in either the $\mathrm{Cu}$ or $\mathrm{Zn}$ treatments, suggesting possible cumulative (e.g. additive) effects of multiple metals. Such differences were not clearly observed, however, in any univariate analysis of individual taxa. For example, the significantly lower average log abundance of Scoloplos cylindrifer in the mixed versus the $\mathrm{Cu}$ treatment may have been caused by combined effects of $\mathrm{Cu}$ and $\mathrm{Zn}$ or because the mixed treatment was simply dominated by the effect of Zn alone (see Fig. 7a). While combined effects of metals may not be clear at the population (individual species) level, in the present study differences in the responses of individual taxa to different metals were reflected at the community-level with the help of multivariate analyses, which distinguished mixed metal treatments from the others. For example, the polychaete Ceratonereis sp. was insensitive to the $\mathrm{Zn}$ treatment but negatively responded to the $\mathrm{Cu}$ and mixed treatments. The polydorid polychaetes, on the other hand, were insensitive to the $\mathrm{Cu}$ treatment but negatively responded to the $\mathrm{Zn}$ and mixed treatments. This differential sensitivity led to community-level effects caused by the simultaneous presence of several different heavy metals.

Because of the fairly short experimental period of $20 \mathrm{~d}$, recolonisation in this experiment is more likely to be explained by the migration of organisms to the sediment discs, rather than by recruitment. Similar experiments examining recolonisation of contaminated sediments have used much longer experimental periods (up to $14 \mathrm{mo}$ ), potentially allowing organisms to colonise sediments through recruitment as well as migration (Trannum et al. 2004, Lu \& Wu 2007). A pilot study in Orewa showed, however, that the sediments spiked with heavy metals were subject to continuous decreases in metal concentrations, so deploying a longer experimental period would not have been feasible here. For this reason, inferences are restricted to short-term effects of heavy metals on colonisation only. The reduced abundances of infauna in metal-spiked 
treatments might be explained either by post-migration mortality or avoidance behaviour. For example, the bivalve Macomona liliana has been shown to be capable of avoiding sediment contaminated with $\mathrm{Cu}$ (Roper \& Hickey 1994, Roper et al. 1995). In contrast, the shells of dead Macomona were frequently observed on the surface of sediment discs spiked with $\mathrm{Cu}$ and Zn during this experiment, suggesting that migration was followed by mortality. Empty Macomona shells were also found, however, on sediment surfaces outside sediment discs, so these shells might simply have been transported to the site from surrounding areas by water movement. This experiment could not distinguish the potential underlying processes driving observed effects (e.g. recruitment, migration followed by mortality or avoidance behaviour). Such mechanisms would need to be examined by subsequent studies to elucidate how contaminants in sediments might ultimately affect population dynamics for individual species across larger spatial scales.

The potential contribution of $\mathrm{Pb}$ to the effects of mixed treatments also remains somewhat unclear: While the $\mathrm{Pb}$ treatment alone did not have any detectable effects on the recolonisation of estuarine fauna, the presence of $\mathrm{Pb}$ might have affected the bioavailability of $\mathrm{Cu}$ and $\mathrm{Zn}$ in the mixed treatment (Gadde \& Laitinen 1974, Benjamin \& Leckie 1981a). Multiple stressors can interact in additive, multiplicative or comparative (the effect of stressors in combination equals the effect of a single, dominant stressor) fashions, and antagonisms or synergisms may also occur (Folt et al. 1999). Crain et al. (2008) have shown that interactions among 3 stressors tended to be synergistic, suggesting that synergistic interactions of multiple stressors might commonly occur in nature. Although strong indication of synergism was not found in the present experiment, it is important to further investigate the potential simultaneous effects these 3 metals as concentrations of $\mathrm{Cu}, \mathrm{Pb}$ and $\mathrm{Zn}$ do tend to correlate with one another in Auckland estuaries.

\section{CONCLUSIONS}

Our field experiment showed that increased amounts of $\mathrm{Cu}$ and $\mathrm{Zn}$ in estuarine intertidal sediments significantly reduced the colonisation of infaunal organisms. Although the current levels of $\mathrm{Pb}$ in the sediments of Auckland's estuaries are unlikely to cause adverse effects on estuarine fauna, its potential contribution to simultaneous effects in the presence of $\mathrm{Cu}$ and $\mathrm{Zn}$, as well as sublethal and chronic effects, still needs to be investigated. Nevertheless, the fact that both $\mathrm{Cu}$ and $\mathrm{Zn}$ generally have negative effects and the fact that different taxa have differential sensi- tivities to these 2 metals demonstrate that their combined effects in contaminated sediments will have important impacts on estuarine community structure as a whole.

Acknowledgements. Thanks are due to the following people who aided in field work: A. Fowler, A. Cowles, K. Morgan, M. Slater and P. Williams. Thanks are also due to X. Lu for his instruction in sediment spiking, R. Clarke for his assistance with sediment and porewater analyses, and Leigh Laboratory general staff (M. Birch, B. Doak, A. Cozens and B. Dobson) for their help with sorting out the practicality of large-scale sediment spiking. We also thank the 4 anonymous reviewers who improved the manuscript through their input. This research was supported by a PhD scholarship to A.F. from Education New Zealand.

\section{LITERATURE CITED}

Adams WJ, Burgess RM, Gold-Bouchot G, Leblanc L, Liber K, Williamson B (2003) Porewater chemistry: effects of sampling, storage, handling, and toxicity testing. In: Carr RS, Nipper M (eds) Porewater toxicity testing: biological, chemical, and ecological considerations. Society of Environmental Toxicology and Chemistry (SETAC), Pensacola FL, p 95-124

Anderson MJ (2001) A new method for non-parametric multivariate analysis of variance. Austral Ecol 26:32-46

Anderson MJ, Ellingsen KE, McArdle BH (2006) Multivariate dispersion as a measure of the beta diversity. Ecol Lett 9: 683-693

Anderson MJ, Gorley RN, Clarke KR (2008) PERMANOVA+ for PRIMER: guide to software and statistical methods. PRIMER-E, Plymouth

ANZECC (2000) Australian and New Zealand guidelines for fresh and marine water quality. Australian and New Zealand Environment and Conservation Council and Agriculture and Resource Management Council of Australia and New Zealand, Canberra

ARC (2004) Blueprint for monitoring urban receiving environments. Technical Publication No 168 revised edn. Auckland Regional Council, Auckland

Avery EL, Dunstan RH, Nell JA (1996) The detection of pollutant impact in marine environments: condition index, oxidative DNA damage, and their associations with metal bioaccumulation in the Sydney rock oyster Saccostrea commercialis. Arch Environ Contam Toxicol 31:192-198

Bat L, Raffaelli D (1998) Sediment toxicity testing: a bioassay approach using the amphipod Corophium volutator and the polychaete Arenicola marina. J Exp Mar Biol Ecol 226: 217-239

Benjamin MM, Leckie JO (1981a) Competitive adsorption of $\mathrm{Cd}, \mathrm{Cu}, \mathrm{Zn}$, and $\mathrm{Pb}$ on amorphous iron oxyhydroxide. J Colloid Interface Sci 83:410-419

Benjamin MM, Leckie JO (1981b) Multiple-site adsorption of $\mathrm{Cd}, \mathrm{Cu}, \mathrm{Zn}$, and $\mathrm{Pb}$ on amorphous iron oxyhydroxide. J Colloid Interface Sci 79:209-221

> Blanchard AL, Feder HM (2003) Adjustment of benthic fauna following sediment disposal at a site with multiple stressors in Port Valdez, Alaska. Mar Pollut Bull 46:1590-1599

> Borgmann U, Norwood WP (1999) Assessing the toxicity of lead in sediments to Hyalella azteca: the significance of bioaccumulation and dissolved metal. Can J Fish Aquat Sci 56:1494-1503 
Borja A, Franco J, Perez V (2000) A marine biotic index to establish the ecological quality of soft-bottom benthos within European estuarine and coastal environments. Mar Pollut Bull 40:1100-1114

Breitburg D, Seitzinger S, Sanders J (1999) (eds) The effects of multiple stressors on freshwater and marine ecosystems. Limnol Oceanogr 44:737-972 (Preface)

Bryan GW, Langston WJ (1992) Bioavailability, accumulation and effects of heavy metals in sediments with special reference to United Kingdom estuaries: a review. Environ Pollut 76:89-131

Bryan GW, Gibbs PE, Hummerstone LG, Burt GR (1987) Copper, zinc, and organotin as long-term factors governing the distribution of organisms in the Fal Estuary in southwest England. Estuaries 10:208-219

> Byers SC, Mills EL, Stewart PL (1978) A comparison of methods of determining organic carbon in marine sediments, with suggestions for a standard method. Hydrobiologia 58: 43-47

> Chapman PM, Long ER (1983) The use of bioassays as part of a comprehensive approach to marine pollution assessment. Mar Pollut Bull 14:81-84

Chen M, Ma LQ (2001) Comparison of three aqua regia digestion methods for twenty Florida soils. Soil Sci Soc Am J 65: 491-499

Clarke KR, Gorley RN (2006) PRIMER v6: User manual/tutorial. PRIMER-E, Plymouth

- Crain CM, Kroeker K, Halpern BS (2008) Interactive and cumulative effects of multiple human stressors in marine systems. Ecol Lett 11:1304-1315

> De Luca-Abbott S (2001) Biomarkers of sublethal stress in the soft-sediment bivalve Austrovenus stutchburyi exposed in situ to contaminated sediment in an urban New Zealand harbour. Mar Pollut Bull 42:817-825

Folt CL, Chen CY, Moore MV, Burnaford J (1999) Synergism and antagonism among multiple stressors. Limnol Oceanogr 44:864-877

Gadde RR, Laitinen HA (1974) Studies of heavy metal adsorption by hydrous iron and manganese oxides. Anal Chem 46:2022-2026

> Gale SA, King CK, Hyne RV (2006) Chronic sublethal sediment toxicity testing using the estuarine amphipod, Melita plumulosa (Zeidler): evaluation using metal-spiked and field-contaminated sediments. Environ Toxicol Chem 25: 1887-1898

Green M, Timperley M, Collins R, Senior A and others (2004a) Prediction of contaminant accumulation in the Upper Waitemata Harbour - results: zinc. Technical Publication No 260, Auckland Regional Council, Auckland

Green M, Timperley M, Williamson B (2004b) Prediction of contaminant accumulation in the Upper Waitemata Harbour-results: copper. Technical Publication No 259, Auckland Regional Council, Auckland

Halpern BS, Selkoe KA, Micheli F, Kappel CV (2007) Evaluating and ranking the vulnerability of global marine ecosystems to anthropogenic threats. Conserv Biol 21:1301-1315

> Heugens EHW, Hendriks AJ, Dekker T, Van Straalen NM, Admiraal W (2002) A review of the effects of multiple stressors on aquatic organisms and analysis of uncertainty factors for use in risk assessment. Crit Rev Toxicol 31: 247-284

> Hewitt JE, Anderson MJ, Hickey CW, Kelly S, Thrush SF (2009) Enhancing the ecological significance of sediment contamination guidelines through integration with community analysis. Environ Sci Technol 43:2118-2123

- Hickey CW, Roper DS, Holland PT, Trower TM (1995) Accumulation of organic contaminants in two sediment-dwelling shellfish with contrasting feeding modes: deposit- (Macomona liliana) and filter-feeding (Austrovenus stutchburyi). Arch Environ Contam Toxicol 29:221-231

> Josefson AB, Hansen JLS, Asmund G, Johansen P (2008) Threshold response of benthic macrofauna integrity to metal contamination in West Greenland. Mar Pollut Bull 56:1265-1274

Kelly S (2007) Marine receiving environment stormwater contaminants: status report 2007. Technical Publication No. 333, Auckland Regional Council, Auckland

Kennedy P (2003) The effects of road transport on freshwater and marine ecosystems. Prepared by Kingett Mitchell Limited for New Zealand Ministry of Transport, http:// www.transport.govt.nz/research/Documents/stormwater_ road_transport_effects.pdf

King CK, Dowse MC, Simpson SL, Jolley DF (2004) An assessment of five Australian polychaetes and bivalves for use in whole-sediment toxicity tests: toxicity and accumulation of copper and zinc from water and sediment. Arch Environ Contam Toxicol 47:314-323

> Lande E (1977) Heavy metal pollution in Trondheimsfjorden, Norway, and the recorded effects on the fauna and flora. Environ Pollut 12:187-198

Lavolpe M, Greco LL, Kesselman D, Rodríguez E (2004) Differential toxicity of copper, zinc, and lead during the embryonic development of Chasmagnathus granulatus (Brachyura, Varunidae). Environ Toxicol Chem 23: 960-967

Laws EA, Hiraoka J, Mura M, Punu B, Rust T, Vink S, Yamamura C (1994) Impact of land runoff on water quality in an Hawaiian estuary. Mar Environ Res 38:225-241

> Lee HW, Bailey-Brock JH, McGurr MM (2006) Temporal changes in the polychaete infaunal community surrounding a Hawaiian mariculture operation. Mar Ecol Prog Ser 307:175-185

Lenihan HS, Peterson CH, Kim SL, Conlan KE and others (2003) Variation in marine benthic community composition allows discrimination of multiple stressors. Mar Ecol Prog Ser 261:63-73

> Lindegarth M, Underwood AJ (2002) A manipulative experiment to evaluate predicted changes in intertidal, macrofaunal assemblages after contamination by heavy metals. J Exp Mar Biol Ecol 274:41-64

Long ER, MacDonald DD, Smith SL, Calder FD (1995) Incidence of adverse biological effects within ranges of chemical concentrations in marine and estuarine sediments. Environ Manage 19:81-97

> Lu L, Wu RSS (2007) A field experimental study on recolonization and succession of subtidal macrobenthic community in sediment contaminated with industrial wastes. Mar Pollut Bull 54:195-205

> Lu X, Bibby RL, Ford RB, Webster-Brown JG (2008) Creating metal spiked bed sediments: a case study from Orewa estuary, New Zealand. Environ Toxicol Chem 27: 2088-2096

Lundquist CJ, Pilditch CA, Cummings VJ (2004) Behaviour controls post-settlement dispersal by the juvenile bivalves Austrovenus stutchburyi and Macomona liliana. J Exp Mar Biol Ecol 306:51-74

Marsden ID, Wong CHT (2001) Effects of sediment copper on a tube-dwelling estuarine amphipod, Paracorophium excavatum. Mar Freshw Res 52:1007-1014

McArdle BH, Anderson MJ (2001) Fitting multivariate models to community data: a comment on distance-based redundancy analysis. Ecology 82:290-297

> Millward RN, Carman KR, Fleeger JW, Gambrell RP, Portier R (2004) Mixtures of metals and hydrocarbons elicit complex 
responses by a benthic invertebrate community. J Exp Mar Biol Ecol 310:115-130

Moreira SM, Lima I, Ribeiro R, Guilhermino L (2006) Effects of estuarine sediment contamination on feeding and on key physiological functions of the polychaete Hediste diversicolor: laboratory and in situ assays. Aquat Toxicol 78:186-201

Morrisey DJ, Underwood AJ, Howitt L (1996) Effects of copper on the faunas of marine soft-sediments: an experimental field study. Mar Biol 125:199-213

Norkko J, Hewitt JE, Thrush SF (2006) Effects of increased sedimentation on the physiology of two estuarine soft-sediment bivalves, Austrovenus stutchburyi and Paphies australis. J Exp Mar Biol Ecol 333:12-26

Parsons TR, Maita Y, Lalli CM (1984) A manual of chemical and biological methods for seawater analysis. Pergamon Press, New York

Roper DS, Hickey CW (1994) Behavioural responses of the marine bivalve Macomona liliana exposed to copper- and chlordane-dosed sediments. Mar Biol 118:673-680

Roper DS, Nipper MG, Hickey CW, Martin ML, Weatherhead MA (1995) Burial, crawling and drifting behaviour of the bivalve Macomona liliana in response to common sediment contaminants. Mar Pollut Bull 31:471-478

Rygg B (1985) Effect of sediment copper on benthic fauna. Mar Ecol Prog Ser 25:83-89

Thrush SF, Hewitt JE, Hickey CW, Kelly S (2008) Multiple stressor effects identified from species abundance distributions: interactions between urban contaminants and species habitat relationships. J Exp Mar Biol Ecol 366:

Editorial responsibility: Matthias Seaman,

Oldendorf/Luhe, Germany
$160-168$

Timperley M, Williamson B, Mills G, Horne B, Hasan MQ (2005) Sources and loads of metals in urban stormwater. Technical Publication No ARC04104, Auckland Regional Council, Auckland

- Trannum HC, Olsgard F, Skei JM, Indrehus J, Øverås S, Eriksen J (2004) Effects of copper, cadmium and contaminated harbour sediments on recolonisation of soft-bottom communities. J Exp Mar Biol Ecol 310:87-114

Tsutsumi H (1987) Population dynamics of Capitella capitata (Polychaeta; Capitellidae) in an organically polluted cove. Mar Ecol Prog Ser 36:139-149

Warwick RM (2001) Evidence for the effects of metal contamination on the intertidal macrobenthic assemblages of the Fal estuary. Mar Pollut Bull 42:145-148

> Watzin MC, Roscigno PR (1997) The effects of zinc contamination on the recruitment and early survival of benthic invertebrates in an estuary. Mar Pollut Bull 34:443-455

Webster-Brown J (2005) A review of trace metal transport and attenuation in surface waters. In: Moore TA, Black A, Ceneno JA, Harding JS, Trumm DA (eds) Metal contaminants in New Zealand: sources, treatments, and effects on ecology and human health. Resolutionz Press, Christchurch, p 193-212

Wilcock RJ, Smith TJ, Pridmore RD, Thrush SF, Cummings VJ, Hewitt JE (1993) Bioaccumulation and elimination of chlordane by selected intertidal benthic fauna. Environ Toxicol Chem 12:733-742

> Wilson JG (2002) Productivity, fisheries and aquaculture in temperate estuaries. Estuar Coast Shelf Sci 55:953-967

Submitted: July 27, 2009; Accepted: December 11, 2009 Proofs received from author(s): February 24, 2010 